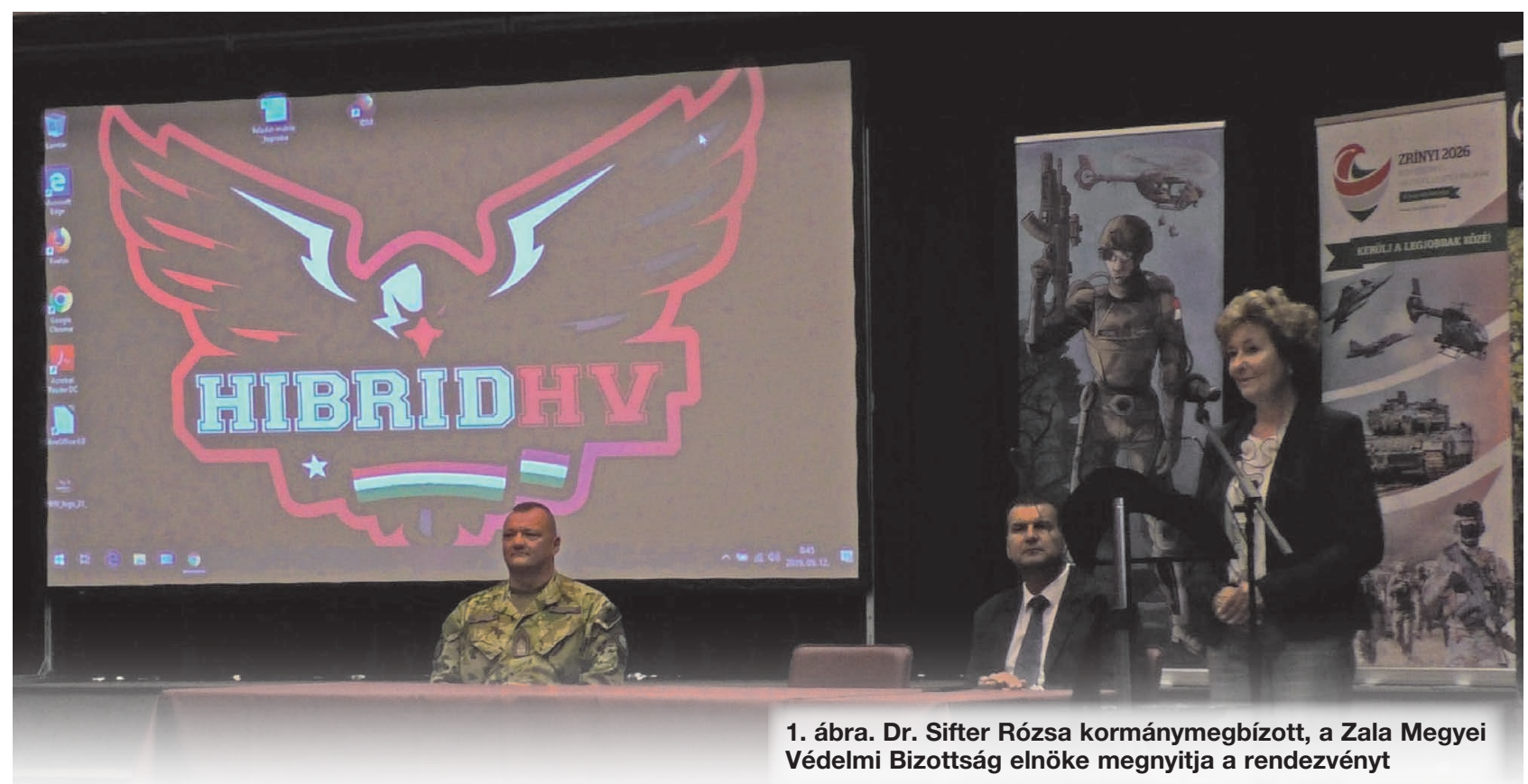

Berta Gábor*

\title{
Hibrid honvédelmi verseny középiskolásoknak
}

$\mathrm{M}$ erőben új kihívás elé állította a középiskolásokat a Magyar Honvédség. Az e-sport és a hagyományos sport ötvöződött szeptember 12-én Zalaegerszegen, az Apáczai Művelődési Központban, ahol a Zala Megyei Védelmi Bizottság szervezésében, a Honvédelmi Minisztérium Védelmi Igazgatási Főosztályának és a Magyar Honvédség Modernizációs Intézetének támogatásával országos Hibrid honvédelmi versenyt rendeztek.

Szarka Csaba ezredes, a Magyar Honvédség Modernizációs Intézetének Innovációs Stratégiai osztályvezetője köszöntőjében hangsúlyozta, hogy többek között az itt versenyző fiatalokból kerülhetnek majd ki a most beszerzés alatt álló világszínvonalú haditechnikai eszközök kezelői, parancsnokai.

A Magyar Honvédségnek napjainkban nagy kihívást jelent az utánpótlás biztosítása, így ennek a versenynek kiemelt jelentősége lehet a toborzásban, mivel a fiatalok körében oly népszerű e-sportokon keresztül találja meg az utat a honvédelem ügye iránt érdeklődőkhöz. A verseny helyszínén egyértelmúen látszott, hogy a fiatalok nagy örömmel próbálták ki a virtuális eszközöket. Élményeiket

ÖSSZEFOGLALÁS: Több országos és regionális szervezet összefogásával úttörő jelentőségü, a fiatal generációt az innovációs technológia segítségével megszólító honvédelmi versenyt rendeztek 2019-ben Zalaegerszegen. Segítségével hatékonyabbá válhat a Magyar Honvédség toborzása, illetve jelentősen fejlődhet a társadalmi megitélése.

KULCSSZAVAK: honvédelmi verseny, toborzás, pályára irányítás, honvédelmi nevelés

\footnotetext{
* Őrnagy, MH MI. ORCID: 0000-0003-2504-4205
}

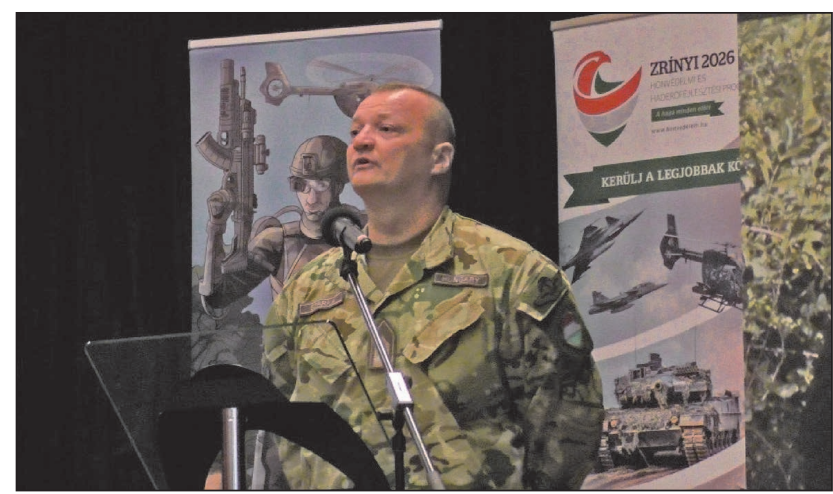

2. ábra. Szarka Csaba ezredes, a Magyar Honvédség Modernizációs Intézetének Innovációs Stratégiai osztályvezetője köszöntötte a résztvevőket

később vélhetően megosztották társaikkal, így a következő megmérettetésre már jóval nagyobb számban érkeznek majd kortársaik. A versenyen részt vettek a Magyar Hon-

ABSTRACT: In 2019, together with several national and regional organizations, a ground-breaking defence competition was organized in Zalaegerszeg to appeal to the younger generation using the innovative technology. With the help of it, the recruitment of the Hungarian Defence Forces can be made more efficient and its social image can be significantly improved.

KEY WORDS: defence competition, recruitment, guidance to a profession, national defence education 


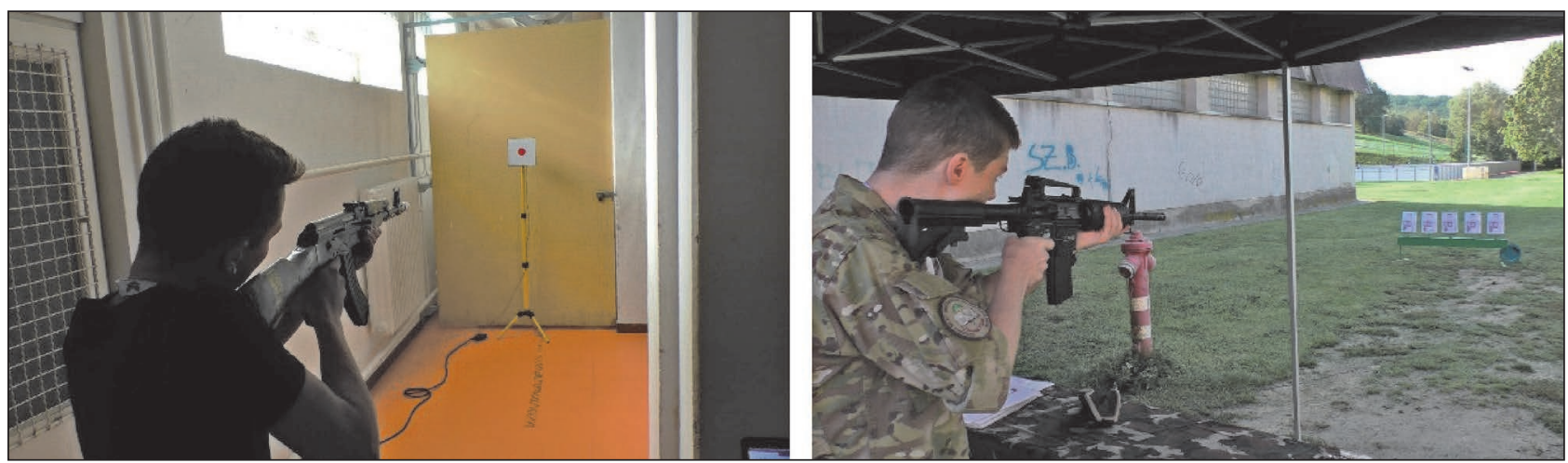

3. ábra. Kiképzési feladatokra átalakított AK-63 lézerpuska és M4 airsoft fegyver

védség toborzói is, akiknek remek alkalma nyílt a motivált fiatalokkal még jobban megismertetni a katonai pálya által kínált lehetőségeket.

Ez a különleges megmérettetés lehetőséget biztosított a diákoknak arra, hogy kipróbálják magukat a virtuális és a fizikai térben egyaránt. Egyebek mellett drónvezetés, airsoft lövészet és tájékozódási futás is szerepelt a versenyszámok között. Különlegességnek számított, hogy az egész versenyt egy külön erre a célra fejlesztett szoftver vezérelte, és a csapattagok a saját mobiltelefonjaikon jelentkezhettek be az egyes megmérettetésekre. A speciális informatikai háttérprogram $26 \mathrm{db}$ - foglalkozásvezetői és versenyzőknek biztosított - laptopon futott. A drónfeladat megoldását 3 RDS (Real Drone Simulator) programmal futó PC segítette. A verseny során 5 PS4 konzolt használtak a fiatalok, ebből 4-et VR- (virtual reality - virtuális valóság) szemüveggel támogatva. 2 XBOX konzol Kinect (mozdulatra reagáló) kiegészítővel szintén rendelkezésre állt. A toborzás támogatására jelen

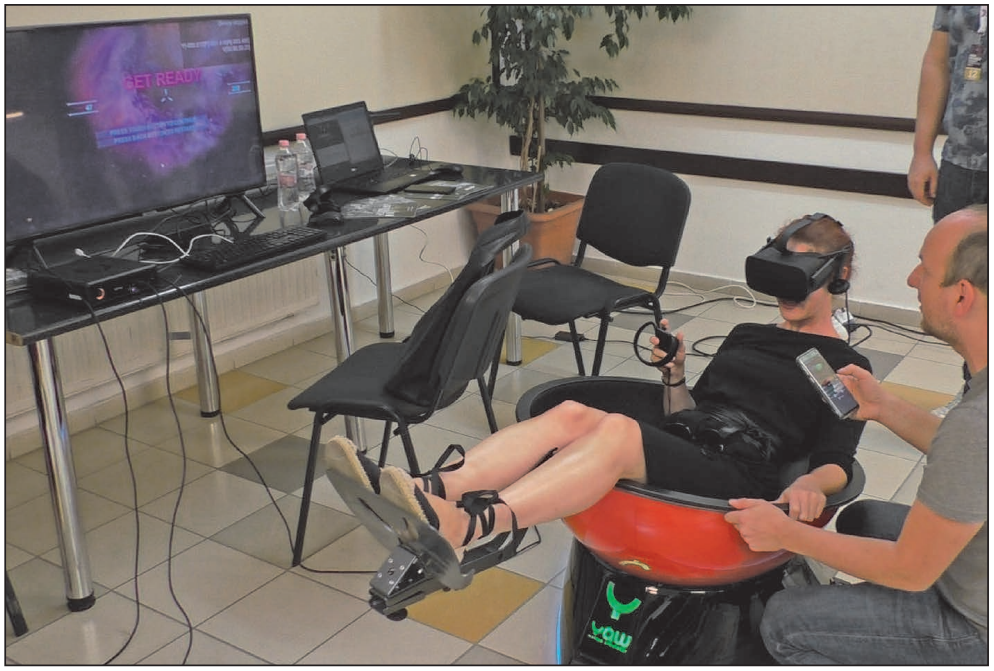

5. ábra. A Yaw VR mozgásszimulátor egy magyar startup vállalkozás (Intellisense) fejlesztése

volt a Honvédelmi Minisztérium Zrínyi Térképészeti és Kommunikációs Szolgáltató Közhasznú Nonprofit Kft. médiakamionja is JAS-39 Gripen szimulátorral. A verseny katonai jellegét az átalakított AK-63 lézerpuska, valamint $2 \mathrm{db}$ M4 airsoft fegyver emelte ki.

A helyszínen megjelent érdeklődők az aulában kivetített képernyőről, percről percre követhették a verseny állását. A csapatok - a szervezők által kitalált előmeneteli rendszer segítségével - bizonyos feladatok teljesítését követően magasabb rendfokozatokat kaphattak. A szoftveres háttérnek köszönhetően, a szervezők a verseny befejezését követően azonnal eredményt hirdettek.

\section{4. ábra. VR-szemüveggel támogatott szimulációs feladat}

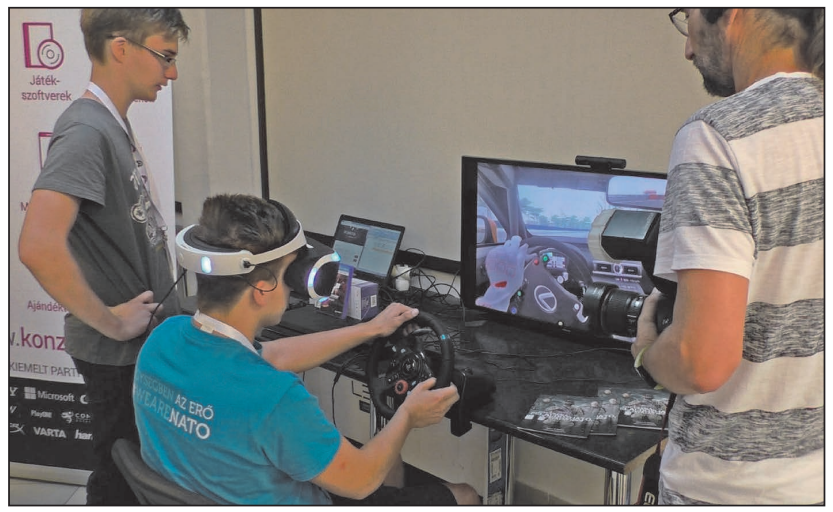

A rendezvényen nyolc megyéből tizenkét csapat félszáz versenyzője mérte össze erejét. A jó hangulatú feszített tempójú versenyben végül a szekszárdi Csapó Dániel Mezőgazdasági Szakgimnázium, Szakközépiskola és Kollégium csapata bizonyult a legjobbnak és vehette át a védelmi bizottság által alapított vándordíjat. Ők éreztek rá legelőször a verseny lényegére, arra a taktikára, amely szerint az egyes versenyszámban kiemelkedő csapattagok úgy is gyarapíthatják a csapatuk pontszámait, ha minél többször teljesítik az adott versenyszámot. Ehhez résen kellett lenniük és gyorsan regisztrálni az adott versenyszámra, hiszen a program csak korlátozott számú jelentkezőt regisztrált.

$A z$ rendezvény eredményhirdetése előtt Sághegyi Attila alezredes röviden értékelte a versenyt. Kiemelte a fiatalok helytállását, szólt a frissen megszerzett tapasztalatokról és összefoglalta azokat a technikai elemeket, amelyeken változtatni, finomítani kell a jövőben a még dinamikusabb, élménydúsabb rendezés érdekében. Megítélése és a viszszajelzések szerint a verseny rendkívül sikeres volt, és kiváló lehetőséget biztosított a fiatalok számára a sportszerü, XXI. századi versenyzésre.

A verseny zárásaként Szarka Csaba ezredes megköszönte a szervezőknek a rendezvény létrehozását, illetve a csapatoknak az odaadó versenyzést. Felhívta a fiatalok figyelmét, hogy történelmi pillanat részesei, nemzetközi összehasonlításban is egészen egyedi megmérettetés részesei lehettek.További sikeres tanulmányokat kívánva búcsúzott a résztvevőktől remélve, hogy sokukkal hamarosan szerződéses vagy hivatásos katonaként találkozik majd a jövőben. 